\title{
BENJAMIN CONSTANT AND CONSTITUTIONALISM
}

\author{
K. Steven Vincent \\ North Carolina State University
}

\begin{abstract}
SUMMARY: I. THE HISTORICAL CONTEXT .- II. POLITICAL SOVEREIGNTY AND THE PROTECTION OF RIGHTS.- III. POLITICAL INTERCHANGE, NEGOTIATION, AND COMPROMISE.- IV. RELIGIOUS TOLERATION.- V. THE DANGER OF FANATICISM.- VI. ANCIENT VERSUS MODERN LIBERTY.- VII. PLURALISM
\end{abstract}

\begin{abstract}
Benjamin Constant (1767-1830) was one of the most famous liberal politicians and writers of the Bourbon Restoration in France (1814-1830). In 1814 and 1815, he wrote a number of notable works on constitutionalism. This article places these writings in their historical context, and summarizes Constant's liberal pluralist constitutional philosophy. Constant insisted on the protection of rights, on a representative system of politics based on popular sovereignty, on the separation and balance of power, and on religious toleration. He worried about the destabilizing effects of "fanaticism," and argued that a liberal constitutional regime would not endure unless citizens embraced a politics that permitted contestation, negotiation, and compromise.
\end{abstract}

Keywords: Benjamin Constant, constitutionalism, liberalism, Boubon Restoration

Benjamin Constant (1767-1830) was one of the most famous liberal politicians of the Bourbon Restoration (1814-1830), serving in the Chamber of Deputies 18191822 and 1824-1830. He participated frequently in the debates that took place on the floor of the Chamber, ${ }^{1}$ devoted his considerable energy to organizational activities of the Liberal Opposition, ${ }^{2}$ and wrote hundreds of journal articles. ${ }^{3} \mathrm{He}$ referred to politics as his "vocation" and clearly enjoyed his public role. ${ }^{4}$

${ }^{1}$ Discours de M. Benjamin Constant à la Chambre des Députés, 2 t. (Paris: Ambroise Dupont et Compagnie, 1827 et 1828).

2 The essential secondary scholarship for Constant during this period is the recent work by Robert Alexander, Re-Writing the French Revolutionary Tradition: Liberal Opposition and the Fall of the Bourbon Monarchy (Cambridge: Cambridge University Press, 2003); and idem. "Benjamin Constant as a Second Restoration Politician," The Cambridge Companion to Constant, Helena Rosenblatt, ed. (Cambridge: Cambridge University Press, 2009), pp. 146-70. Also see Elizabeth Schermerhorn, Benjamin Constant, pp. 310-67; Paul Bastid, Benjamin Constant et sa doctrine, vol. 1 (Paris: Colin, 1966); Ephraïm Harpaz, L’Ecole libérale sous la Restauration, le "Mercure" et la "Minerve," 1817-1820 (Genève: Droz, 1968); and, K. Steven Vincent, Benjamin Constant and the Birth of French Liberalism (New York: Palgrave, 2011).

${ }^{3}$ Ephraïm Harpaz has edited numerous volumes of Constant's articles. Benjamin Constant, Recueil d'articles 1795-1817, introduction, notes et commentaries par Éphraïm Harpaz (Genève: Droz, 1978); Benjamin Constant, Recueil d'articles: Le Mercure, La Minerve et La Renommée, 2 v., introduction, notes et commentaries par Éphraïm Harpaz (Genève: Droz, 1972); Benjamin Constant, Recueil d'articles 1820-1824, introduction, notes et commentaries par Éphraïm Harpaz (Genève: Droz, 1981); Benjamin Constant, Recueil d'articles 1825-1829, texte établi, introduit, annoté et commenté par Éphraïm Harpaz (Paris: Champion, 1992); Benjamin Constant, Recueil d'articles 1829-1830, texte établi, introduit, annoté et commenté par Éphraïm Harpaz (Paris: Champion, 1992). 


\section{K. Steven Vincent}

Constant was also well known for his writings on constitutionalism. Most of these were originally published in 1814 and 1815: De l'esprit de conquête et de l'usurpation [published in 1814]; 5 Réflexions sur les constitutions, la distribution des pouvoirs, et les garanties, dans une monarchie constitutionnelle [1814];6 De la responsabilité des ministres [1815];7 and Principes de politique applicables à tous les gouvernements représentatives et particulièrement à la Constitution actuelle de la France [1815]. ${ }^{8}$ These works drew from his writings of the 1790s, especially from the unpublished manuscript Fragments d'un ouvrage abandonné sur la possibilité d'une constitution républicaine dans un grand pays [published only in 1991]; ${ }^{9}$ and, also from the 1806 manuscript Principes de politique applicables à tous les gouvernements [published only in 1980]. ${ }^{10}$ The writings of 1814-15 present a

The number of articles is overwhelming, especially given Constant's other engagements. In the compilation of Constant's articles from the end of December 1816 to early May 1820, there are 188 articles (more than one article/week). [Benjamin Constant, Recueil d'articles: Le Mercure, La Minerve et La Renommée, 2 v.] Robert Alexander points out that in the three months of April, May, and June 1829, Constant published 24 articles (approximately two articles/week). ["Benjamin Constant as a Second Restoration Politician," p. 150.]

${ }^{4}$ Constant, in a characteristic statement, wrote to his cousin Rosalie: "Ma mission est de faire, se faire se peut, triompher un gouvernement constitutionnel." [Benjamin Constant à Mademoiselle Rosalie de Constant (7 novembre 1820), Lettres de Benjamin Constant à sa famille 1775-1830, p. 552.]

5 De l'esprit de conquête et de l'usurpation, dans leurs rapports avec la civilization Européenne, Oeuvres complètes, t. VIII (Tübingen, Max Niemeyer Verlag, 2005), pp. 527-822. References to The Spirit of Conquest and Usurpation and their relation to European Civilization will be to the translation by Biancamaria Fontana, in Benjamin Constant, Political Writings (Cambridge: Cambridge University Press, 1988). [Henceforth referred to as The Spirit of Conquest and Usurpation.] However, at times I have modified the translation.

6 Réflexions sur les constitutions, les distributions des pouvoirs, et les garanties, dans une monarchie constitutionnelle, in Oeuvres complètes, t. VIII, pp. 929-1283. [Henceforth referred to as Réflexions sur les constitutions.]

7 De la responsabilité des ministres, in Oeuvres complètes, t. IX (Tübingen, Max Niemeyer Verlag, 2001), pp. 413-96.

8 Principes de politique applicables à tous les gouvernements représentatives et particulièrement à la Constitution actuelle de la France, Oeuvres complètes, t. IX, pp. 653-858. References to the 1815 published version of Principles of Politics Applicable to All Representative Governments will be to the translation by Biancamaria Fontana, in Benjamin Constant, Political Writings. [Henceforth referred to as Principles of Politics [1815]]. However, at times I have modified the translation.

9 Constant, Fragments d'un ouvrage abandonné sur la possibilité d'une constitution républicaine dans un grand pays, ed. Henri Grange (Paris: Aubier, 1991) [henceforth Fragments]. Constant worked on this manuscript from 1798 to 1807; parts of it were clearly completed before Napoleon's coup in 1799, others clearly after the coup but before the proclamation of the Empire in 1804.

There are two versions of the manuscript, one in Paris and one in Lausanne, but the differences are not significant. There is a thorough discussion of the different texts and Constant's revisions in Oeuvres complètes, $\mathrm{t}$. IV (Max Niemeyer Verlag: Tübingen, 2005), pp. 355-96. The editors of the Oeuvres complètes decided to entitle the work De la possibilité d'une constitution républicaine dans un grand pays: fragments d'un ouvrage abandonné because this title occurred in a manuscript of some of Constant's additions to the text(s). Both of the complete manuscripts, however, have the title Fragments d'un ouvrage abandonné sur la possibilité d'une constitution républicaine dans un grand pays, which is the title under which the work was first published in 1991. I have chosen to retain the original title. References will be to the 1991 edition of Henri Grange.

${ }^{10}$ Principes de politique applicable à tous les gouvernements, texte établi par Etienne Hofmann (Genève: Droz, 1980). References to the 1806 version of Principles of Politics Applicable to All Governments will be to the 
comprehensive view of the constitutional liberalism that Constant supported during his political career. ${ }^{11}$ This consistency is also evidenced in his famous 1819 address "De la liberté des anciens comparée à celle des modernes."12

\section{THE HISTORICAL CONTEXT}

The historical context of these works is the First French Empire, the first Restoration of the Bourbons (in 1814), and Napoleon's return to France during the Hundred Days (1815). There have been criticisms of Constant's political maneuverings during this period. Not infrequently, he has been presented as an opportunist rallying to each new regime, and therefore guilty of embracing inconsistent political ideals. The evidence, however, suggests a quite different conclusion. Constant desired to see established in France a constitutional and parliamentary regime that protected individual liberties and separated and balanced power. ${ }^{13}$ What changed was the environment, especially the institutional context, within which his goals were pursued. French politics were in continuous flux during these years, and Constant's strategy was to advance his political agenda with the recognition of adjustments required because of this flux. This is illustrative of Constant's pragmatic approach to politics. It is fair, nonetheless, to raise the issue of political opportunism, as Constant clearly desired to be an effective political actor. Even with these activities taken into consideration, however, one must conclude that there was a remarkable consistency in his political philosophy and, more specifically, in his view of the principles that must undergird and animate a constitutional regime.

Constant was responding to the quick pace of events in the period 1812-1815. He interpreted the defeat of Napoleon's Grand Army in Russia as a hopeful sign that European peace could be regained after years of war, and that France could be constitutionally rehabilitated. He worked for a few months in late-1813 and early1814 to advance the candidacy of Charles-Jean-Baptiste Bernadotte, the Swedish Crown Prince who was viewed as a possible future occupant of the French throne.

translation by Dennis O’Keeffe (Indianapolis: Liberty Fund, 2003). [Henceforth referred to as Principles of Politics [1806]]. However, at times I have modified the translation.

11 Hofmann emphasizes the more abstract and systematic nature of Constant's writings beginning with the 1806 Principes de politique. Andreas Kalyvas and Ira Katznelson argue that there is an intellectual evolution in Constant's political thought from a "republican origins" in the Fragments, through a 'pure' liberalism in the 1806 version of Principes, to a "moderated" and "syncretic" liberalism in the 1815 version of Principes. [See Etienne Hofmann, Les "Principes de politique" de Benjamin Constant: la genèse d'une oeuvre et l'évolution de la pensée d leur auteur (1789-1806), 2 t. (Genève: Droz, 1980); Kalyvas and Katznelson, Liberal Beginnings: Making a Republic for the Moderns (Cambridge: Cambridge University Press, 2008), pp. 146-75.] The argument here is that there is more substantive continuity than evolution.

12 "De la Liberté des anciens comparée à celle des modernes," in Benjamin Constant, Ecrits politiques, ed. Marcel Gauchet (Paris: Gallimard, 1997), pp. 589-619.

13 This point is made convincingly by Olivier Devaux and Kurt Kloocke in the various introductions to the works in volume IX of the Oeuvres complètes. 
When this hope evaporated (Bernadotte returned to Sweden 29-30 March 1814), he turned his attentions to other ways to influence events.

Constant returned to Paris on April 15, 1814, four days after the abdication of Napoleon, and threw himself into preparing texts for publication. On April 21, his short article "Des Révolutions de 1640 et 1688 en Angleterre, et de celle de 1814 en France" appeared in the Journal des Débats. ${ }^{14}$ This article encouraged the French to see the end of the Empire as the chance to initiate an époque of constitutional liberty similar to that instituted in England in 1688 (when, in his words, the monarchy "was happily and skillfully reorganized") and to avoid the reactionary potential of a restoration of 1660 (when the English monarchy unfortunately had left "a clear field for vengeful and arbitrary actions"). ${ }^{15}$ The article drew heavily from Constant's earlier work Des suites de la contre-révolution de 1660 en Angleterre, published in 1799.16 The next day, on April 22, the third edition (but first Paris edition) of De l'esprit de conquête et de l'usurpation appeared.

A month later, on May 24, Constant published Réflexions sur les constitutions, la distribution des pouvoirs, et les garanties, dans une monarchie constitutionnelle, his first extensive published manuscript on constitutional issues. With this work, Constant hoped to influence the form that the Charter, being formulated by Louis XVIII and his advisors, would take. ${ }^{17}$ Relevant here are other details of the historical context. Louis XVIII, having returned from exile, refused to adhere to the so-called Constitution sénatoriale adopted by the Imperial Senate on April 6, 1814. This constitution had specified that it was a contract between the King and the people (similar to the formulation in the French Constitution adopted in 1830). The Charter that Louis XVIII finally "offered" to the people of France on June 4, 1814, retained the traditional legitimacy and prerogatives of the King. It noted the continuity of the new regime with the Old Regime, though of course interrupted by the "parenthesis" of the revolution. As Béatrice Fink has cogently observed, with Réflexions sur les constitutions Constant was conducting "a preventative war" against the centralizing tendencies of the proposed Charter, arguing that the separation and balance of power were essential. 18

A central argument of this work, and of all the others he published at this time, was that it was important to avoid a return to the absolutism and reactionary culture of the Ancien Régime and to reconcile the return to monarchy with the revolutionary spirit of individual liberty. Constant also reasoned, especially in

14 “Des Révolutions de 1660 et de 1688 en Angleterre, et de celle de 1814 en France," Journal de Débats [21 avril 1814], in Oeuvres complètes, t. VIII, pp. 915-23.

15 Ibid. p. 921.

16 De suites de la contre-révolution de 1660 en Angleterre, in Oeuvres complètes, t. I (Tübingen: Max Niemeyer Verlag, 1998), pp. 643-79.

17 The Declaration of Saint-Ouen, announcing a new constitution, was made on 2 May 1814; the Charter was promulgated on 4 June 1814. Constant's Réflexions sur les constitutions appeared between these two dates (though probably too late to influence decisions).

18 Béatrice Fink, "Introduction," Réflexions sur les constitutions, Oeuvres complètes, t. VIII, p. 933. 
Réflexions sur les constitutions and in De la responsabilité des ministres (published after the promulgation of the Charter), that there should be a separation of the power of the monarch from the power of the executive branch of government. This was a refashioning of the proposal for a "neutral power" that had been central to his unpublished work, Fragments d'un ouvrage abandonné; and it remained an integral part of his subsequent constitutional proposals, like that in the 1815 version of Principes de politique. The "neutral power" that was recommended in these new works, however, was no longer identified with a council of lifetime elected officials, as had been the case in the earlier manuscript, but rather with the hereditary monarch. Constant obviously was making adjustments to accommodate the new political realities, though the overall institutional structure of government remained consistent. ${ }^{19}$ We have more to say about Constant's constitutional proposals below.

Constant's most notorious and controversial political maneuverings occurred following the return of Napoleon from Elba in March 1815 - that is, during the "Hundred Days." In 1814, Constant had reemerged, because of the publications mentioned above, as a strong political voice in support of the constitutional monarchy and critical of Napoleon. De l'esprit de conquête et de l'usurpation, especially, was vehement in its attacks on Napoleon, on the Empire, and on the military culture that the Napoleonic wars had fostered in France domestically. Réflexions sur les constitutions also criticized Napoleon, for violating "the independence of courts of justice," for stifling the liberty of the press, and for "surrounding this beautiful country with intellectual deserts." 20 De la responsibilité des ministres lamented that Napoleon had created a large number of "henchmen and spies" who, like himself, were "imposed on the nation by force." Napoleon, Constant wrote, had "brought pressure on the nation . . . with lies and despotic force." 21 Constant penned more criticisms of Napoleon in articles that appeared in the Journal des Débats on March 11 and March 19, 1815. In the latter, he wrote that Napoleon "is Attila, is Genghis Khan, more terrible and more odious because of the resources of civilization which he has at his disposal."22 Napoleon arrived at the Tuileries the following day (March 20); and Constant prudently took refuge in the American Embassy and subsequently fled the city.

To everyone's surprise, however, Constant returned to Paris on March 27 and subsequently agreed to work in Napoleon's new administration. On April 14 he had a personal meeting with Napoleon, and came to the conclusion that he was, in his own words, "an astonishing man." At this meeting, Constant agreed to compose amendments to the constitution (these became l'Acte additionnel aux constitutions de l'Empire, frequently referred to as "la Benjamine"23). Subsequently, he met

19 See Lucien Jaume's "introduction" to De la responsibilite des ministres for an excellent discussion of the continuities and differences of function of the "neutral power" as presented in the Fragments and of the constitutional monarch as presented in the works of the first restoration. Oeuvres complètes, t. IX, pp. 415-38.

\footnotetext{
20 Réflexions sur les constitutions, Oeuvres complètes, t. VIII, pp. 1054-55.

${ }^{21}$ De la responsibilité des ministres, Oeuvres complètes, t. IX, p. 458.

22 Cited in "Introduction" to Principes de Politique [1815], Oeuvres complètes, t. IX, p. 656.

${ }^{23}$ Act additionnel aux Constitutions de l'Empire, in Oeuvres complètes, t. IX, pp. 561-623.
} 
frequently with the Emperor to work out the details, and agreed a few weeks later (on April 20) to be a conseiller d'État. This was quickly followed by the publication, in May 1815, of his new political work, Principes de politique, which supported l'Acte additionnel and, obviously, assumed the continued existence of the Empire.

Constant was criticized at the time, not least by his former lover and companion Germaine de Staël and her friends, for his willingness to work with Napoleon and to accept a position in his administration. ${ }^{24}$ And, his seeming opportunism during the Hundred Days has been noted frequently ever since. In 1819-20, Constant himself publicly addressed the issue. ${ }^{25}$ He justified his actions by arguing that the royalists in 1815 had not taken sufficient measures to protect the constitutional monarchy and, foolishly, they had refused reforms and had alienated and betrayed liberals like him who were willing to compromise with the regime. Pushed away from the monarchy by these reactionary policies, liberals had turned to the Emperor as the more likely defender of the liberties they valued. Knowing today what we do of Ultra policies at this time, it is not difficult to understand why Napoleon could appear more attractive to liberals in early 1815 than the Bourbons. Nonetheless, it was a risky move. A central issue, obviously, was Constant's assessment of what Napoleon would do. Constant's actions in 1815 suggest, and his subsequent discussions of his actions claim, that he believed the reestablishment of the Empire would not return France to tyranny. He permitted himself to hope that, with proper guidance, a new Napoleonic regime - one that respected liberty - could be institutionalized. And, he viewed his own actions to be a contribution to just such a progressive development.

However naïve this looks in retrospect, it is not inconsistent with the stance visà-vis regimes that Constant adopted throughout his life. He always emphasized his pragmatism: how it was necessary to constantly assess and reassess the actions one should take to bring about a reasonable government; how it was necessary to assess and reassess the actions one should take to advance the goals of political and civil liberties. "I have always believed," he wrote in 1820 ,

and this belief has been the rule of my conduct, that in matters of government it is necessary to start from the point where one is; that liberty is possible under all forms [of government]; that liberty is the goal, and forms [of government] are only the means; that there are some individual rights, some sacred rights, some indispensable guarantees that one ought to introduce under the republic as under the monarchy. . . . As a consequence, it is never against a form [of government] that I have argued; there is not any that I proscribe, none that I

\footnotetext{
${ }^{24}$ Not all contemporaries were so severe on Constant. Montlosier, for example, wrote to Prosper de Barante on 22 April 1814: "Notre conseiller d'Etat n'a pas tout à fait le certitude de l'avenir, mais il en a l'espérance. Ses anciens articles contre [Napoléon], ne font rien, il est populaire." [cited in Oeuvres completes, t. IX:1, p. 10.]

25 Benjamin Constant, Mémoires sur les Cent-Jours, Oeuvres complètes, t. XIV (Tübingen: Max Niemeyer Verlag, 1993).
} 
demand exclusively. That which exists has the advantage of being, and in order to substitute that which does not exist for that which does requires sacrifices that are always good to avoid. 26

Not only was Constant's strategy in 1815 consistent with his strategy at other times, so were his political principles. An examination of the political writings of the Empire, first Restoration, and Hundred Days, demonstrates this doctrinal consistency.

\section{POLITICAL SOVEREIGNTY AND THE PROTECTION OF RIGHTS}

The best-known aspects of Constant's liberal constitutional theory are his defense of individual liberties and his criticism of Jean-Jacques Rousseau's theory of political sovereignty. ${ }^{27}$ The defense of rights has many dimensions, but central to them all, according to Constant, should be the assurance of free expression, both oral and written, and the protection of all the means of communicating the ideas generated by free expression. ${ }^{28}$ Closely connected with the protection of these liberties, as we see in detail below, was Constant's concern to provide individuals access to the process of political representation. And both of these were intimately tied to Constant's views concerning political sovereignty.

The question of sovereignty is the focus of the opening section of Constant's 1806 manuscript Principes de politiques, of a central chapter of De l'Esprit de conquête et de l'Usurpation, and of the first sections of the published 1815 version of Principes de politiques. Constant agreed with Rousseau that all political authority must come from the general will, marking his distance from those who had argued that authority should be vested in a hereditary ruler and his distance from those who believed that authority descended from some transcendent force or being. But if Constant agreed with Rousseau's argument of the ultimate source of political sovereignty, he strongly dissented from Rousseau's argument that the authority of the general will over the individual was unlimited. As he wrote in 1806:

In my view, this is the theory we must hold responsible for most of the difficulties the establishment of freedom has encountered among various nations, for most of

\footnotetext{
26 Mémoires sur les CentJours, p. 116.

27 In addition to my Benjamin Constant and the Birth of French Liberalism, see the recent studies of Helena Rosenblatt, Liberal Values: Benjamin Constant and the Politics of Religion (Cambridge: Cambridge University Press, 2008); Emmanuelle Paulet-Grandguillot, Libéralisme et démocratie: De Sismondi à Constant à partie du Contrat social (1801-1806) (Genève: Éditions Slatkine, 2010); and, Aurelian Craiutu, A Virtue for Courageous Minds: Moderation in French Political Thought, 1748-1830 (Princeton: Princeton University Press, 2012).

28 Book VII and Book IX of Principles de politique [1806] focus, respectively, on rights and the legal safeguards necessary to protect them. Chapter VII of Réflexions sur les constitutions focuses on individual rights. Chapters 16, 18, and 19 of Principes de politique [1815] focus, respectively, on liberty of the press, the liberty of the individual, and judicial guarantees.
} 


\section{K. Steven Vincent}

the abuses which worm their way into all governments of whatever type, and indeed for most of the crimes which civil strife and political upheaval drag in their wake. It was just this theory which inspired our Revolution and those horrors for which liberty for all was at once the pretext and the victim. ${ }^{29}$

Unlimited political power concentrated anywhere was dangerous.

The omnipotent nation is as dangerous as a tyrant, indeed more dangerous. . . . The mistake of Rousseau and of writers who are the greatest friends of freedom, when they grant society a boundless power, comes from the way their ideas on politics were formed. They have seen in history a small number of men, or even one alone, in possession of immense power, which did a lot of harm. But their wrath has been directed against the wielders of power and not the power itself. Instead of destroying it, they have dreamed only of relocating it. 30

In the version of Principes de Politiques published in 1815, Constant wrote in the same vein:

No authority upon earth is unlimited, neither that of the people, nor that of the men who declare themselves their representatives, nor that of the kings, by whatever title they reign, nor, finally, that of the law, which, being merely the expression of the will of the people or of the prince, according to the form of government, must be circumscribed within the same limits as the authority from which it emanates. ${ }^{31}$

Political sovereignty must be limited to leave as great a space as possible for the liberties of individuals, which must be protected. "[T]here is a part of human existence which necessarily remains individual and independent and by right beyond all political jurisdiction. Sovereignty exists only in a limited and relative way."32 Constant quoted with approval a passage of a speech Siéyès had made in the Convention in 1795: "In political life one communalizes, in the name of public power, as little as possible and only what is necessary for maintaining each person in his rights and duties. Power on this scale is far short of the exaggerated ideas with which people have blithely invested what they call sovereignty."33

Governments have legitimate roles to play, to maintain internal order and repulse foreign invasion, and these justify the levying of taxes. But, individual rights must be respected, and political authority legally restricted. What individual

${ }_{29}$ Principles of Politics [1806], this quote, p. 13. Rousseau is the focus of the five of the first six chapter of Book I, pp. 6-21.

30 Ibid. pp. 20-21.

${ }^{31}$ Principles of Politics [1815], this quote, p. 180.

32 Principles of Politics [1806], p. 31. There is an identical passage in Principles of Politics [1815], p. 177.

33 Principles of Politics [1806], p. 27. 
liberties should be protected? "Citizens possess individual rights independently of all social and political authority, and any authority which violates these rights becomes illegitimate. The rights of the citizens are individual freedom, religious freedom, freedom of opinion, which includes the freedom to express oneself openly, the enjoyment of property, a guarantee against all arbitrary power."34 The final six chapters of the 1815 version of Principes de politique are devoted to discussions of the liberties that must be protected. 35

Constant explicitly attacked Hobbes as "the man who most cleverly reduced despotism to a theoretical system." He was mistaken to argue that the sovereign could always act or speak in the name of the people; mistaken to claim that the unified body of the people existed only when represented by the sovereign. ${ }^{36}$ Hobbes had attempted to justify absolute sovereignty and, further, had argued that sovereignty should be located in one place. Rather, according to Constant, "Democracy is power in the hands of all, but power only in such measure as is needed for the security of society."37

Constant also rejected a strictly utilitarian argument, refusing to reduce the protection of liberty to a matter of calculation. ${ }^{38}$ Strictly quantitative consideration of the consequences of actions was important, but it was insufficient because it could lead to self-interested action masquerading for what was best for all. This was, in part, because such calculations relied on an unreliable sentiment.

The principle of utility . . awakens in the human heart the hope of advantage rather than the feeling of duty. Now, the evaluation of an advantage is arbitrary: it is the imagination that settles it. But neither its errors nor its whims can change the idea of duty. ${ }^{39}$

Constant was sensitive to how utilitarian justifications could be given to actions that violated individual freedoms, as had happened during the radical phase of the French Revolution. The principle of utility needed to be buttressed by the protection of rights.

You can find utilitarian reasons for all orders and prohibitions. Forbidding citizens to leave their houses would prevent all the crimes which are committed on the highways. To have them appear every morning in front of their town hall would stop vagabonds, thieves, and dangerous men from hiding in the big cities

${ }^{34}$ Principles of Politics [1815], p. 180.

35 Ibid. pp. 261-305.

36 See Annabel Herzog, "Hobbes and Corneille on Political Representation," The European Legacy, 14:4 (2009), pp. 379-89.

37 Principles of Politics [1806], pp. 21-22.

38 Ibid. pp. 39-42, 47-9.

39 Ibid., p. 40. 
on the lookout for criminal opportunities. This is the kind of thinking which in our day turned France into one vast prison. . . . Set [authority] up without limits and you fall once again into the bottomless abyss of arbitrary rule. . . Law alone provides a guarantee." 40

This did not imply that all laws should always be respected. There were clearly times when laws encroached upon freedoms, and other times when laws violated morality. Constant argued that if individual freedoms were transgressed or if unjust laws were implemented, individuals should passively resist. ${ }^{4}$ His counsel was to act morally and to avoid fanaticism. This meant that laws should generally be followed, but there were times when it was appropriate, indeed a moral duty, to rebel against them. In his own words, "Obedience to the law is without doubt a duty; but this duty is not absolute, but relative." 42

Constant also warned against precipitous revolutionary action, however, echoing reservations he had expressed in the 1790s when he observed with concern the viciousness of revolutionary actors on the political extremes. His recommendation, as before, was for moderation and forgiveness.

Two movements are natural to any nation overthrowing institutions it finds oppressive or vicious. The first is to wish to see everything destroyed and constructed anew, the second to display implacable severity to those who profited from the vices of the former institutions. These two movements are precisely what make revolutions dire, what takes them beyond the people's needs, prolongs their duration, and jeopardizes their success. ${ }^{43}$

He suggested that there were two stages to revolutions, the first when the old order is overthrown, and the second "when by means of an artificial prolongation of a movement no longer nationwide, there is an attempt to destroy everything contrary to the viewpoint of a few." Thinking comparatively, he commended those revolutions, like the English and the American, which stopped at the moderate first stage, and condemned those revolutions that moved to the second stage. "[I]n the case of nations which reject all their memories and think everything must be changed, reformed, and built from scratch, revolutions never end. Interminable divisions tear these people apart."44

40 Ibid. pp. 48-9.

41 "A positive, general, unrestricted duty, every time a law seems unjust, is to avoid becoming its executor. This passive resistance does not carry with it any upheavals, revolutions or disorders. Nothing justifies the man who lends his assistance to a law which he believes iniquitous." Principles of Politics [1815], p. 181.

42 Principles of Politics [1806], p. 401.

43 Ibid. p. 407.

44 These quotes, ibid. p, 408. 
The actors in radical revolutions are also dangerous. They have the illusion, according to Constant, that their violent coercive measures in the present will be legitimated by the future perfect system that the revolution will create. They fail to recognize, however, that no system attains perfection, and that it is likely that the coercive measures to bring about the promised future will in fact not be justified by the result. "Thus you are not as you imagine doing uncertain and temporary harm to achieve positive and lasting good; you are doing certain and positive harm in exchange for uncertain, relative, and temporary advantage." 45 The consequence of such coercive actions was all too often the unfortunate creation of a new tyrannical order, albeit one constructed in the name of freedom. It could be even more oppressive than a traditional tyranny.

Tyrannical government being denounced, the most tyrannical of governments is constructed. . . The war against public attitudes is less evil when the despotism is blatant, since it is not of the essence of despotism to depend on [these public attitudes]. . . . Institutions claiming to be free ones, when they employ despotic means, bring together all the ills of a monarchy under an oppressive tyrant with all those of a republic rent by factions. Quiet men are persecuted for being apathetic, ardent men because they are dangerous. Servitude guarantees no rest; human activity lacks all purpose and joy. Freedom is adjourned. . . . ${ }^{46}$

Constant's experiences during the various phases of the revolution led him to be suspicious of impatient leaders, factions, and institutions that employed coercive methods to hasten change. They foolishly ignored the state of public opinion, and they dangerously pushed aside, in their haste to realize reform, political dialogue and negotiation. This was precisely what Napoleon had done. In some stunningly modern-sounding pages in De l'esprit de conquête et de l'usurpation, Constant specified that unlike previous forms of despotism, modern [Napoleonic] ururpation was a new form of tyranny because it demanded assent while "counterfeiting liberty."

Despotism stifles freedom of the press; usurpation parodies it. . . Despotism, in a word, rules by means of silence; usurpation condemns him to speak, it pursues him into the most intimate sanctuary of his thoughts, and, by forcing him to lie to his own conscience, deprives the oppressed of his last remaining consolation.

When a people is but enslaved without being abased, there is still the possibility of an improvement in its situation. ... [U]surpation abases a people at the same time as oppressing it. It makes it accustomed to trample under foot what it used to respect, to court what it despised. . . .47

\footnotetext{
45 Ibid. p. 410.

46 Ibid. p. 412.

47 The Spirit of Conquest and Usurpation, pp. 96-7.
} 
A healthy polity avoided despotism and usurpation. It allowed discussion, unlike the silence of despotism; and it encouraged free discussion, unlike the forced conformity of usurpation.

\section{POLITICAL INTERCHANGE, NEGOTIATION, AND COMPROMISE}

Constant valorized political interchange, but he insisted that it was a mistake to believe that political contestation naturally led to an agreement about appropriate policy, to some uniform political agenda. It was to be expected that individual interests were not synonymous with the general interests; it was to be expected that the local interests of one region would not be identical with the local interests of another region. Politics, properly constituted, was the arena where negotiation and compromise occurred. There should be no expectation that differences would be subsumed into some fatuous unity.

A hundred deputies elected by a hundred different parts of the country bring individual interests and the local preferences of their constituents inside the assembly. This base is useful to them. Forced to debate together, they soon notice respective sacrifices which are indispensable. They strive to keep these at a minimum, and this is one of the great advantages of this type of appointment. Necessity always ends by uniting them in common negotiation, and the more sectional the choices have been, the more representation achieves its general purpose. ${ }^{48}$

This is the pluralist dimension of Constant's liberalism.

Constant worried that if elected representatives forgot their attachments to the interests of their local constituents, they would create an imagined uniformity at the expense of real differences. He believed there was a natural tendency for a gulf to open up between the represented and their elected representatives, and that this was exacerbated if there were not an expectation that representatives "represent" the interests of their constituents.

Assemblies, however sectional their composition, tend all too often to contract an esprit de corps which isolates them from the nation. Placed in the capital, far from the section of the nation which elected them, representatives lose sight of the usages, needs, and way of life of their constituents. They lend themselves to general ideas of leveling, symmetry, uniformity, mass changes, and universal recasting, bringing upset, disorder, and confusion to distant regions. It is this disposition we must combat, because it is on particular memories, habits, and regional laws that the happiness and peace of a province rest. 49

\footnotetext{
48 Principles of Politics [1806], pp. 327-28.

49 Ibid. p. 328.
} 
Constant's conception of the importance of representatives remaining close to the particular interests of their constituents contrasted with the view of contemporaneous theorists who claimed that representatives should transcend the narrow and parochial interests of their locality. The abbé Sieyès, for example, was suspicious of particular interests and argued that politicians should focus on abstract, general questions. Representatives, therefore, should focus on issues that transcended local concerns. Here, of course, Sieyès echoed Rousseau's misgivings about confusing the interests of particular individuals or associations with the interests of the whole political community. Sieyès, in effect, transported Rousseau's political agenda of realizing a unified national will into the institutional context of a representative system. Constant was suspicious of the underlying assumption of both, believing that differences were natural and healthy. "Unanimity always suggests an unfavorable campaign, and with good reason; because there never has been, on important and complicated questions, unanimity without bondage [sans servitude]."50

This was closely connected with Constant's conviction that the natural tendency of power was to corrupt, and that the natural tendency of representatives who distanced themselves from their constituents was not to pursue the general interest but rather their own interest. Given that this was the case, he argued that representatives would make better decisions if they remained accountable to their constituents and kept their interests clearly in view. ${ }^{51}$ He advocated what we would term transparency.

This goal also underlay Constant's concern for the responsibility of ministers. He maintained that they were not above the law and, like every other citizen, could be prosecuted for breaking laws. ${ }^{52}$ On the other hand, ministers making decisions in the performance of their official duties were to be assessed by political, not legal procedures, meaning that they could be removed from office but not prosecuted for crimes. "The subtle spirit of jurisprudence is opposed to the nature of those great questions which must be considered from the public, national, sometimes even European perspective."53 More dangerous, however, was the impulse of governments to override legality and expect their ministers and agents obediently to execute orders without reflection.

50 "De la liberté des brochures, des pamphlets et des journaux, considérée sous le rapport de l'intérêt du Gouvernement," [1814], Oeuvres complètes, t. IX, p. 78.

51 Bryan Garsten points out that Constant cited the influence of Aristotle and Machiavelli on this point. See "Behind the Nostalgia for Ancient Liberty," European Journal of Political Theory, 8:3 (2009), pp. 401-11. See also Giovanni Paoletti, Benjamin Constant et les anciens: politique, religion, histoire, trans. (from Italian into French) by Marie-France Merger (Paris: Champion, 2006).

52 De la responsabilité de ministres, Oeuvres complètes, t. IX, pp. 439-96.

As Lucien Jaume points out, Constant wished to separate the "responsibility" which members of government have to conduct policy, from the "power" to dominate. To control the latter, Constant looked to legal prosecution for illegal acts. To control the former, he looked in 1815 to the power vested in the "neutral power" (of the monarch) to dismiss governments and Assemblies that overstepped their authority. See Jaume's "introduction" to De la responsabilité de ministres, Oeuvres complètes, t. IX, pp. 415-38.

${ }^{53}$ See Principles of Politics [1815], pp. 227-50; this quote, p. 235; and De la responsabilité de ministres. 
[T] he possessors of power, convinced, in spite of examples, of the eternal tenure of their authority, search only for pliant instruments who will obey them blindly; they see nothing in human intelligence but an importunate motive to resistance. 54

Given his suspicion of power, it is not surprising that Constant dreaded any governmental system that favored one branch over another. His proposal for a "neutral power" - which after 1814 was to be the monarch - with power to dissolve the legislature and/or dismiss the ministers, was expressly to prevent either the ministry or legislature from becoming too dominant. 55

The desire to keep vigilant oversight of government personnel also explains Constant's advocacy of the direct election of representatives, in opposition to the indirect election proposals of contemporaries like Sieyès, Pierre-Louis Roederer, or Jacques Necker. The latter method of election distanced representatives from their constituents, according to Constant, and as a consequence gave them too much autonomy vis-à-vis the electorate. Constant favored a closer association, advocating what we would term accountability. Again, he viewed the essential element of politics as the open negotiation of different interests and regional needs. He believed that this would be best carried out by the transparent interaction among representatives who were accountable to their constituents.

As this indicates, Constant valorized the exchange of views in legislative assemblies. It was in popularly-elected assemblies that national political discussion could take place and that the honest negotiation of differences could be achieved. He favored frank discussion over formal written speeches.

It is only when orators are forced to speak extensively that a proper discussion is set in train. Everyone, struck by the arguments he has just heard, is naturally led to examine them. Those arguments impress his mind even if he does not realize it. He cannot banish them from his memory. The views he has encountered combine with and modify those he already holds, suggesting to him answers which present the same issue from different points of view.

When orators confine themselves to reading out what they have written in the silence of their study, they no longer discuss, they amplify. They do not listen. . .

${ }^{54}$ De la responsabilité de ministres, Oeuvres complètes, t. IX, p. 450.

55 Mary S. Hartman has suggested that Constant did not believe in 1814-15 that France was ready for an English-style parliamentary government. Moreover, she argues that Constant's "constitutional schemes for France reveal him to be more sympathetic to the executive power, which is consistently granted far more authority than the legislative." ["Benjamin Constant and the Question of Ministerial Responsibility in France, 1814-1815." Journal of European Studies, vi (1976), pp. 248-61; this quote p. 258.] Constant did worry about an overly-powerful legislative branch, no doubt because of his assessments of the constitutions of 1791 and 1795 and of the revolutionary regimes of the 1790s. He also, however, worried about an overly-powerful executive branch. 
. They do not examine the opinion [of others]. . . In this way there is no discussion. 56

The contrast with Rousseau, again, is intriguing. Rousseau was so concerned about the power of amour propre to distort political deliberations that he wished to eliminate all public interchange; that is, he wished to confine people to "the silence of their study" where he imagined they would better recognize the general will. Constant agreed with Rousseau that prepared political speeches were tailor-made for flights of eloquence that would allow individuals to indulge their lamentable "desire to impress." 57 But, Constant disagreed with Rousseau's argument that political deliberations necessarily degenerated to such a level. Indeed, frank and honest exchanges of views, and the ongoing negotiation of differences, were exemplary political activities, central to the health of a representative constitutional system.

The tyranny of the majority, translated into government policy, also must be avoided. "The assent of the majority is not enough in all circumstances to render its actions lawful. ... When a government of any sort puts a threatening hand on that part of individual life beyond its proper scope, it matters little on what such authority is based, whether it calls itself individual or nation." 58 Constant recognized that individuals, like governments, could make bad decisions, but he worried more about the consequences of the heavy-handed actions of majorities or of government than he did about the actions of individuals. This was because governments and majorities have powers that individuals do not possess; and power often brings recklessness and coercion. "There is something about power which more or less warps judgment. Force is far more liable to error than weakness is. Force finds resources in itself. Weakness needs thought. All things equal, it is always likely that the government will have views which are less just, less sound, and less impartial than those of the governed."59

When. . a mistaken majority oppresses the minority or, which happens far more often, when a ferocious and noisy minority seizes the name of the majority to

56 Principles of Politics [1815], pp. 221-25; this quote, p. 222.

57 Constant wrote the following of the "need to impress":

This need, which degenerates into a kind of fury, is the more dangerous in so far as it does not originate in the nature of man, but is a social creation. . . . Consequently, it does not restrain itself, like those natural passions which are exhausted by their own duration. Sentiment does not stop it, as it has nothing in common with sentiment. Reason is impotent against it, for it is not a question of being convinced, but of convincing. Even fatigue does not calm it; as he who experiences it fails to note his own sensations, but observes only those it produces in other people ...

[O]ur vanity is humble, as well as unrestrained: it aspires to everything but is contented with very little. By looking at the pretensions it displays, one would think it insatiable. But watching it clinging to the smallest achievements, one admires its frugality." [Principles of Politics [1815], p. 223].

58 Principles of Politics [1806], p. 31.

59 Ibid. p. 54. 
tyrannize society, to what does it lay claim in justification of its outrages? The sovereignty of the people, the power of society over its members, the abnegation of individual rights in favor of the society, that is to say, always principles of government, never principles of freedom. 60

Constant obviously had anxieties about the ability of any political system to protect the interests of individuals. Nonetheless, he was optimistic that a truly representative system, even one based on a limited franchise, was the best hope for modern societies. He also believed that this system would promote the easing of tensions between the classes, because the elected representatives, in order to be elected, would need to consider the interests of all.

Constant was also optimistic that representative elections would keep citizens involved in politics rather than allowing them to focus on their narrow personal interests. Making an argument that Alexis de Tocqueville would later make famous, Constant feared that looking exclusively to one's own concerns at the expense of public involvement naturally conformed with populations resigning themselves to rule by political elites. "Citizens are interested in their institutions only when they are called to participate in them with their votes. Now, this interest is indispensable in the formation of public spirit, that power without which no freedom lasts, that guarantee against all the perils, always invoked in certain countries without it ever being created." 61

These were not new positions. Constant and his then-companion Germaine de Staël had written similar passages before. As early as 1798, Staël had written that one of the main causes of the malheurs that had plagued the revolution in France was "the false application of the principle of the sovereignty of the people in representative government."62 The correct application of this principle, according the Staël, was the creation of a constitutional order that would divide executive power into several parts and destroy the privileges of class. ${ }^{63}$ The correct application, in short, would be the division of political sovereignty. ${ }^{64}$ Twenty years later, reflecting on the Revolution and Napoleon, Staël described without regret the passing of monarchical "despotism" in which there was a union of executive and legislative powers in the hands of one individual, ${ }^{65}$ but she lamented that the

\footnotetext{
60 Ibid. p. 384.

61 Ibid. p. 332.

62 Madame de Staël, Des circonstances actuelles qui peuvent terminer la Révolution et des principes qui doivent fonder la République en France [1798], ed. Lucia Omacini (Genève: Droz, 1979), p. 39.

63 Ibid., pp. 155-207.

64 There were different opinions among liberals at this time concerning how much separation of power there ought to be. Staël and her father Jacques Necker opposed too much separation, arguing that the executive should have a role in the discussion of laws and that he should have a suspensive (though not an absolute) veto. The essential work here is Henri Grange, Les Ideés de Necker (Université de Lille III, 1973), pp. 552-82.
}

65 Madame de Staël, Considérations sur la Révolution Française [1818] (Paris: Charpentier, 1862), t. 1, p. 12. 
Revolutionaries had failed to see the importance of separating political power among various institutions. "Checks are necessary to all forms of authority." 66 Unfortunately, in Staël's estimation, during the early phase of the Revolution a number of factors had converged to frustrate the triumph of liberty. The King had moved too slowly to make concessions; abstract ideas had become the norm among the people and their leaders; economic and financial matters were neglected; flaws were introduced into the new constitution of 1791 (placing of all power in the Assembly); and, the populace had descended into a state of insurrection, inaccessible to reason. Staël argued that these factors led to the political actors on the extremes uniting against the moderates, which in turn led to the overturn of the monarchy, the outbreak of war, and the growth of fanaticism. The result was the Terror and fifteen months of "anarchy" with the Jacobins in control - "arbitrary will, without limits, was their doctrine." 67

After the Terror, according to Staël, and after a brief respite during the early years of the Directory, France stumbled into a political stew (following the Fructidor "coup" of 1797) where personal interest replaced patriotism, constitutionalism died, and Bonaparte maneuvered himself into power. Attached to no principles except his own egotism and personal ambition, Bonaparte established and organized a despotic regime, sacrificing others and the nation to his own ends. "It is almost always after periods of civil troubles," Staël lamented, "that tyranny establishes itself."68 Nonetheless, Napoleon would ultimately fail, she reasoned, because it is not possible "to stop the progress of human reason." 69

Constant was also consistent. He wished to see instituted in France a constitutional system that protected liberty and that avoided the concentration of sovereignty in any single body, however representative that body might be. This could be the executive branch of government, as under Napoleon, or the legislative branch, as during the Terror and Directory. Especially important was an independent judiciary, to protect civil liberties like free press and religious toleration. ${ }^{70}$ In his earlier political writings, such as Fragments d'un ouvrage abandonné, Constant had favored a republican form of government for France. In the manuscripts and publications of 1806, 1814, and 1815, he was more agnostic concerning the system he preferred, but he devoted many pages to outlining the institutional checks required for the protection of liberty. What all of his proposals shared was an insistence on the separation and balance of power. In the manuscript of 1806, to offer one example, Constant referred to the Terror and the Constitution of 1795 as suffering from this refusal to balance the power of the legislative branch.

\footnotetext{
${ }^{66}$ Des circonstances actuelles , p. 255.

67 Considérations sur la Révolution Française, t. 1, pp. 453-4.

68 Ibid., t 2, p. 22.

69 Ibid., t. 2, p. 151.

70 Principles of Politics [1815], chapter 19: “On Judicial Guarantees,” pp. 295-302.
} 
[D]uring the ascendancy of our assemblies [that is, during the Terror] no constitution placed real limits on legislative power. Now, when legislative power is quite limitless, when the nation's representatives think themselves invested with boundless sovereignty, when no counterweight exists to their decrees either in executive or judiciary power, the tyranny of those elected by the people is as disastrous as any other, whatever name it bears. The absolute, unlimited sovereignty of the people was transferred by the nation, or as is usual, at least in its name, by those who dominated it, to representative assemblies. These exercised an unparalleled despotism. . . The constitution [of 1795] which first put an end to this period of despotism and madness still did not sufficiently limit the legislative power. It established no counterweight to its excesses. It did not enshrine either the indispensable veto of the executive power or the equally indispensable possibility of the dissolution of the representative assemblies. It did not even guarantee, as do some American constitutions, the most sacred rights of individuals against the encroachments of legislators. ${ }^{71}$

Institutionally, Constant insisted that there must be a separation of power among the various branches of government - what he referred to, echoing a common formula, as "the distribution and balance of powers."72

While Montesquieu and the American founding fathers distinguished three governmental loci of power, Constant distinguished five: the "neutral power" (the monarch or the emperor); the executive power of the ministers; the hereditary assembly ("le pouvoir répresentatif de la durée"); the elected assembly ("le pouvoir répresentatif de l'opinion"); and, the judicial power of the courts. Each had the ability to check the authority of the others. Constant devoted many pages to the details of government organization, always concerned with defining the functions of the various public powers in a manner that prevented any single body from endangering liberty. He discussed the issues of defense and diplomacy, the responsibility of ministers, the power of local authorities, the procedures for the introduction of legislation, the framework for discussion and acceptance or rejection of this legislation. He did not want to paralyze the functioning of government, but he was especially concerned with protecting liberty. He believed that the balance of power, and the "checks" that this inevitably entailed, was the most efficacious governmental structure for achieving this.

Benjamin Constant was committed to a liberal constitutionalism based on a pluralistic conception of political sovereignty. It was essential to separate the power of the state from the absolutist inclinations of the old regime monarchy, from the tyrannical inclinations of the Jacobins, and from the despotic inclinations of Napoleon. This required the firm protection of individual rights, public access to and involvement with the process of representation, and the separation and balance of political power.

\footnotetext{
${ }^{71}$ Ibid. pp. 334-35.

72 Principles of Politics [1815], p. 183.
} 


\section{RELIGIOUS TOLERATION}

Equally important, according to Constant, was religious toleration in the form of protection of religious practice and belief. This did not mean that he was intensely religious or irreligious. Constant never participated in the rituals of an organized religion; he was, as Pierre Deguise argued many years ago, essentially an agnostic. ${ }^{73}$ He recounted in his mémoirs that he grew up a sceptic. ${ }^{74}$ However, while in Brunswick (1788-94), Constant became familiar with German Protestant theology, and was impressed with the degree to which they "discard[ed] the whole dogmatic and miraculous part of Christianity."75 Liberal Protestant theology, with its rejection of religious orthodoxy and its embrace of a spiritual and radically personal religiosity, clearly made an impact on Constant. He preferred the liberal Protestant stance of these Enlightenment scholars to the sacerdotal and sacramental stance of Catholicism. Constant also, for a brief period during the late1790s, was drawn to Theophilanthropy, a non-sacerdotal religion supported by the Directory at the end of the 1790s. But, in spite of his brief attraction to these movements, there is no indication that he became religious in any traditional sense. He did not recommend any formalized religious rituals, nor did he support any established church. ${ }^{76}$ Even more tellingly, he did not articulate any belief in a supreme being, in revelation, or in Jesus as a prophetic personage.

What impressed Constant about religious belief was its psychological power. He suggested that religion was connected with the deepest and most sublime sentiments of humanity, and argued that religion often performed the important function of reinforcing moral behavior. In Principles of Politics, he insisted that religion was "that vague and profound part of our moral sense, which by its very nature defies all the efforts of language."

How would you define the impression of a dark night, of the ocean stretching beyond our sight? How would you define the emotions caused by the songs of Ossian, the Church of St. Peter, meditation upon death, the harmony of sounds

\footnotetext{
73 Pierre Deguise, Benjamin Constant méconnu: le livre “De la Religion” (Genève: Droz, 1966).
}

74"Having been nurtured on the principles of eighteenth-century philosophy and above all on the work of Helvétius, I had no other thought than to contribute my share toward the destruction of what I called prejudices." [Benjamin Constant, Ma vie (Le Cahier rouge), Oeuvres complètes, t. 3:1, Écrits littéraires (1800-1813) (Tübingen: Max Niemeyer Verlag, 1995), p. 129.]

75 I rely here on the discussions of Kurt Klooke and Helena Rosenblatt, who have analyzed an unpublished manuscript that Constant worked on during the 1790s "D'une nouvelle espèce de rapports que les Théologiens modernes voudroient introduire dans la Religion" that is in the Fonds Constant, Bibliothèque cantonale et universitaire de Lausanne. See Klooke, "Religion et société chez Benjamin Constant," in Coppet, Creuset de l'esprit libéral (Aix-en-Provence: Presses Universitaires d'Aix-Marsaille, 2000), pp. 121-33 and Helena Rosenblatt, Liberal Values, esp. pp. 29-32.

76 Rosenblatt has argued that Constant went through a Deistic period during the late-1790s, and that by 1799 was advocating the replacement of Catholicism with Protestantism. [Liberal Values, pp. 37-75.] While Constant clearly preferred Protestantism to Catholicism, I have found no indication that Constant recommended any state-supported church, Protestant or otherwise. He briefly supported Theophilanthropy, I believe, because it encouraged religiosity without bringing with it an institutional shell. 


\section{K. Steven Vincent}

or forms? How would you define reverie, that intimate quivering of the soul, in which all the powers of the senses and thought come together and lose themselves in a mysterious confusion? There is religion at the bottom of all these things. All that is beautiful, all that it intimate, all that is noble, partakes of the nature of religion. ${ }^{77}$

Moreover, the notion of a supreme being could be deeply consoling.

Against so many sorrows we look for consolation everywhere, and all our lasting consolations are religious. When men persecute us, we create for ourselves I do not know what sort of refuge beyond human reach. When we see our dearest hopes, justice, liberty, our country vanish, we have the illusion that somewhere a being exists who will reward us for having been faithful, in spite of the age we live in, to justice, to liberty, to our country. When we mourn a beloved being, we throw a bridge across the abyss, and traverse it with our thought. Finally, when life deserts us, we launch ourselves towards another life. Religion is by its very essence the faithful companion, the ingenious and indefatigable friend of those in misfortune . . . Consoler of our misery, religion is at the same time the most natural of our emotions. ${ }^{78}$

This and other passages indicate deep respect for the psychological and social role that religion could perform.

It is telling, however, that in his discussions of religious belief, Constant employed reflexive verbs-forms - "nous nous créons," "nous nous flattons,"79 indicating a skepticism concerning the existence of an independent power that explained these emotions. Moreover, Constant argued that we should resist giving in to the self-flattery and grandiosity that such experiences might suggest. Nonetheless, he was sensitive to the depth and consoling power of religious belief. Constant's religiosity, then, if one wishes to use this term, was related to his belief that all individuals experience a deeply-felt aspiration to connect with a higher force. He felt it himself. As he put it in 1805, "I have my religious corner. But it is entirely in the form of sentiment, in vague emotions: it cannot be reduced to system."80

Because religious belief performed important functions, Constant was a strident critic of religious intolerance and of government intervention into the arenas of religious belief or religious practice. This did not entail support of organized religion, of which Constant was consistently critical. He distinguished positive religious sentiment, which he believed all individuals experienced, from the

77 Benjamin Constant, Principles of Politics Applicable to All Representative Governments [1815], in Constant's Political Writings, p. 279.

78 Principles of Politics [1815], p. 277.

79 Oeuvres complètes, t. IX:2 (Tübingen: Max Niemeyer Verlag, 2001), p. 821.

80 Benjamin Constant, Journaux intimes (19 février 1805), in Oeuvres complètes, t. VI (Tübingen: Max Niemeyer Verlag, 2002), p. 330. 
unfortunate forms that organized religions had taken historically. He especially disliked sacerdotal religions like Catholicism, preferring Protestantism. But, he insisted on rigorous governmental neutrality. In 1815, he stated categorically "Any government intervention in the domain of religion causes harm."81

He also attacked notions of "civil religion," as those proposed by Rousseau, because they could allow the sovereign to banish anyone who did not subscribe to the "civil profession of faith." In both versions of Principes de politique [1806 and 1815], he attacked Rousseau, "who cherished all theories of liberty, while offering pretexts for every claim that tyranny makes. . . . I know of no system of servitude, which has sanctioned more nefarious errors than the eternal metaphysics of the Social Contract." 82 He quoted with approval the statements of Stanislas-Marie de Clermont-Tonnerre, a moderate royalist, who served briefly as president of the National Assembly before being killed in the uprising of August 10, 1792.

Religion and the state. . . are two quite distinct and separate things, whose bringing together can only distort both one and the other. . . . Each person's religion is therefore his opinion of his relationship to God. Each man's opinion being free, he may take up or not take up such religion. The opinion of the minority cannot be subordinated to that of the majority. No opinion can therefore be commanded by social consensus. What is true of religion is also true of cults. . . . The political body must not have dominion over any religion. It must not reject any of them unless the cult in question is a threat to social order. 83

Constant insisted that civil rights be protected by laws and by an independent judicial order. This applied especially to religious liberty, which was a part of the "private" domain into which the state should not intrude.

\section{THE DANGER OF FANATICISM}

The mental and emotional disposition that would most commonly undermine legal rights, religious toleration, and the division of sovereignty was fanaticism. This was the term that Constant frequently used to refer to the stance of those who wished to impose tyranny. Fanatics wished to reduce the complexity of reality to one simple truth, regardless of the circumstances of time and place, and they wished to impose this simple truth on the complex and differentiated world of human reality. In 1798, his companion Germaine de Staël wrote the following: "Some want to derive everything from rights, others everything from interest, others everything from force, others everything from reason, and drawing some

\footnotetext{
81 Principles of Politics [1815], p. 281.

82 Principles of Politics [1815], p. 275.

83 Stanislas-Marie de Clermont-Tonnerre, Réflexions sur le fanatisme, cited by Constant, Principles of Politics [1815], pp. 145-46.
} 


\section{K. Steven Vincent}

consequences from each of these principles which, having no counterweights, lead all to absurdity. What is necessary is to recognize and to amalgamate rights, interest, force and reason, in order to organize society as wisely as the physical world is organized. . . Fanaticism, the most disastrous of passions, is nothing but the despotism of a single idea over the spirit of man." 84 Constant echoed this in Principes de Politique [1806]:

Fanaticism is nothing save the rule of a single idea which wishes to triumph at any price. It is probably more absurd still when the question is freedom than it is when the question is religion. Fanaticism and freedom are incompatible. One is based on examination; the other forbids research and punishes doubt. The one thinks through and evaluates all views; the other sees the most timid objection as an assault. The one seeks to persuade, the other issues orders. The one, in a word, considers the need for victory a misfortune and treats the vanquished as equals whose rights it is keen to recognize, the other hurls itself on all questions as if on enemy redoubts and sees in its adversaries only still-dangerous captives it must immolate, so as no longer to have to fear them. 85

There existed a political and psychological parallelism: tyranny is brought about by fanatics; a rigid political system is the result of a rigid mindset; a nonpluralistic political order is fostered by individuals with anxious and intolerant personalities. ${ }^{86}$

Severity, injustice, and slights of all kinds on the part of its leaders seem to [fanatics] meritorious acts, as it were gauges of sincerity. It finds the educated bothersome because they find it hard to embrace an opinion without certain restrictions and nuances. It is suspicious of the person of proud spirit, because proud spirits experience some kind of antipathy to the strongest peoples and serve the powerful only with distaste. The only quality [fanaticism] demands are belief and will. It sees in morality obstacles, weakness, and chicanery. ${ }^{87}$

The danger of fanaticism was best countered by a stable constitutional order with the institutional framework outlined above, with the protection of rights, the rule of law, and the division and balance of political sovereignty. And, it was best

${ }^{84}$ Madame de Staël, Des circonstances actuelles qui peuvent terminer la Révolution et des principes qui doivent fonder la République en France, p. 255. Similar attacks of "fanaticism" are in Madame de Staël, Considérations sur la Révolution Française. See, for example, the attack on "philosophical fanaticism" (t. 1, p. 50); and the chapter "du fanatisme politique" (t.1, pp. 427-31).

85 Principles of Politics [1806], p. 415.

86 "La maladie de la Révolution française, c'est de porter le fanatisme dans le raisonnement et d'admettre la cruauté, non seulement par violence, mais par théorie.” Staël, Des circonstances actuelles, p. 297.

87 Principles of Politics [1806], p. 416. 
controlled by a tolerant political culture that encouraged debate and political participation.

\section{ANCIENT VERSUS MODERN LIBERTY}

Constant's most famous writing is an address that he gave in 1819 comparing liberty in the ancient world with liberty in the modern world. ${ }^{88} \mathrm{He}$ argued that the imposition of "ancient" political liberty was inappropriate in the modern age, because historical conditions had changed (for example, the rise of commerce and the emergence of larger political entities) and because the "dispositions of mankind" had changed. Modern individuals best developed their capacities and found their greatest satisfactions, Constant argued, in everyday private activities. They therefore, quite appropriately, demanded greater independence and protection against tyranny. "Modern" liberty, accordingly, required a legal and institutional framework. Civil and political liberties must be protected. ${ }^{89}$

The theme of ancient versus modern liberty was present in a number of Constant's writings after 1806.90 Ancient liberty, according to Constant, was modeled on the small city-states of antiquity where slaves did essential work to sustain the economy. This permitted citizens to be intimately involved in day-to-day political deliberations. Modern liberty, by contrast, was characteristic of larger modern states in which the majority of citizens were directly involved in the production of material wealth, agrarian and commercial. As a consequence, modern citizens were less directly involved in politics, but wished to be protected from the intrusion of the actions of the community and of the state. In the ancient world, "the individual was entirely sacrificed to the collectivity. The ancients. . had no notion of individual rights." 91 In the modern world, the opposite is true: the individual is protected from the collectivity, and the focus is on "his own work, efforts, and individual resources."92 Much of the difference, Constant reasoned, was due to the different historical conditions that existed and, closely related, the different traits of character that obtained. In the ancient world, there were frequent

88 It is famous in part because of Isaiah Berlin's influential essay "Two Concepts of Liberty" (1958), republished in Isaiah Berlin, The Proper Study of Mankind (New York: Farrar, Straus and Giroux, 1998), pp. 191242. Unfortunately, Berlin exaggerated Constant's attachment to "modern" liberty at the expense of "ancient" liberty.

For more balanced analyses, see James Mitchell Lee, "Doux Commerce, Social Organization, and Modern Liberty in the Thought of Benjamin Constant, Annales Benjamin Constant, 26 (2002), pp. 117-49; and Jeremy Jennings, "Constant's Idea of Modern Liberty," The Cambridge Companion to Constant, pp. 69-91.

89 Benjamin Constant, "De la liberté des anciens comparée à celle des modernes," [1819] in Ecrits politiques, ed. Marcel Gauchet (Paris: Gallimard, 1997). References to "The Liberty of the Ancients compared to that of the Moderns" will be to translation by Biancamaria Fontana in Political Writings, pp. 307-28.

90 See, especially, Principles of Politics [1806], pp. 349-80; The Spirit of Conquest and Ururpation, pp. $105-14$.

91 Principles of Politics [1806], p. 351.

92 Ibid. p. 355. 
battles over limited territory, and therefore warfare was the favored methods of gaining riches and power. In the modern world, commerce and trade replaced warfare as the mode for the acquisition of riches and power, and this had led to "a vast softening in manners, more indulgence toward women, more hospitality to strangers, and an exceeding love of individual freedom." 93

Formerly public interest went before safety and individual freedom. Today safety and individual freedom come before the public interest.

Peace, calm, and domestic contentment being the natural and invincible tendency of modern peoples, more sacrifices have to be made for that calm than the ancients made. Disorder is not always incompatible with political freedom, but it always is with civil and individual freedom. ${ }^{94}$

Constant was always careful to point out, however, that the attainment of modern civil liberty would be secure only if some dimensions of ancient political liberty were retained.

The inference I draw from the differences which mark us off from antiquity is absolutely not that we should abolish public safeguards but that we should extend satisfactions. It is not political freedom that I want to renounce, but civil freedom that I am demanding along with other forms of political freedom.

Governments have no more right than before to arrogate to themselves illegitimate power; but legitimate governments have less right than in former times to fetter individual freedom. 95

Summarizing the message of Principles of Politics [1806 version], Constant articulated clearly the point he would publicly make in his famous 1819 address comparing ancient and modern liberty.

That this book has dealt exclusively with issues connected to civil freedom does not mean to insinuate that political freedom is something superfluous. Those who would sacrifice political freedom in order to enjoy civil freedom the more peacefully are no less absurd than those who would sacrifice civil freedom in the hope of further extending political freedom. . . . If political freedom is not one of the individual possessions nature has given man, it is what guarantees them. 96

\footnotetext{
93 Ibid. p. 358.

94 Ibid. p. 364.

95 Ibid. p. 365.

96 Ibid. pp. 386-87.
} 
There was a danger, Constant claimed, that those who govern, however chosen, would find it in their interest to prevent the governed from participating in government. Even a representative system runs this risk. Echoing his earlier writings, he pointed out that the way to contain this danger was three pronged. First, it was necessary to protect individual liberties against the arbitrary actions of government officials. "Wisely established limits [on authority] are the good fortune of [modern] nations because they circumscribe power, in such a way that no one can abuse it."97 In his 1819 speech on liberty, Constant emphasized how important protecting civil liberties was for providing individual security.

[I]t is the right to be subjected only to the laws, and to be neither arrested, detained, put to death or maltreated in any way by the arbitrary will of one or more individuals. The rights of everyone to express their opinion, choose a profession and practice it, to dispose of property, and even to abuse it; to come and go without permission, and without having to account for their motives or undertakings. It is everyone's right to associate with other individuals, either to discuss their interests, or to profess the religion which they and their associates prefer. 98

Secondly, to protect modern liberty, it was necessary to provide individuals access to the process of representation, and to assure that there was no single person or institution that monopolized political power. In Constant's words, imperative was "the creation of various sorts of positions in government invested with different kinds of powers."99 Thirdly, there must be public involvement in political affairs. It was important to keep "alive in the nation - through watchfulness of her representatives, the openness of their debates and the exercise of freedom of the press applied to the analysis of all ministerial actions - a spirit of inquiry, a habitual interest in the maintenance of the constitution of the state, a constant participation in public affairs, in a word a vivid sense of political life."100 The end of his famous 1819 lecture strikes the familiar chord that a culture of public involvement in politics is essential for the protection of liberty and for personal development.

\section{PLURALISM}

Constant embraced a liberal constitutionalism that can fairly be described as pluralism. French pluralism crystallized out of an enormously complex historical inheritance, of course, with elements extending back through early modern political thought to the ancients. Plato, Aristotle, and Polybius, for example, referred to the

\footnotetext{
97 Ibid. p. 393.

98 "The Liberty of the Ancients compared with that of the Moderns," pp. 310-11.

99 Principles of Politics [1806], p. 387.

100 Principles de Politics [1815], p. 239.
} 
importance of separate branches of government. Medieval thinkers not infrequently argued that royal power should be subjected to feudal and popular restraints. British political writers during the stormy seventeenth century argued over the differences among a "mixed government," the "separation of powers," and a "balanced constitution." Finally, American constitutionalists and revolutionaries stressed the importance of federalism and "checks and balances."101 All of these influenced French thinkers of the early nineteenth century like Constant, though in ways difficult to trace with any precision.

By this period, there were three dimensions of what legitimately can be referred to as French pluralism, though the term was not in use, and all of these no doubt influenced Constant. ${ }^{102}$ There was a political dimension that rejected the idea of unitary sovereignty; an administrative dimension that argued for local power vis$\grave{a}$-vis the central power; and, a religious dimension that insisted on religious toleration. The call for administrative decentralization during the early nineteenth century was made by individuals from across the political spectrum: ultra-royalists, liberals, socialists, and anarchists. All criticized excessive administrative centralization and called for the rehabilitation of local powers, of "intermediary" institutions, and/or of "associations" - though there were strong disagreements concerning which local/intermediate/associative institutions were to be rehabilitated. The call for political pluralism, to offer a second example, was made by ultra-royalists of the chambre introuvable of 1815-16, who found themselves out of step with Louis XVIII's policy of accommodating changes introduced by the Revolution, as well as by liberals of the same era like Constant who wished to emphasize the importance of legislative power vis-⿳亠丷-vis the monarch. What both groups shared was a deep suspicion of the calls for national unity that characterized all "factions" and "parties" - that is, all opposition political groups - as detrimental to the public good.

A comprehensive history of early-nineteenth century French pluralism remains to be written. ${ }^{103}$ It will need to consider the strong contrary forces that

101 A good general history is M.J.C. Vile, Constitutionalism and the Separation of Powers (Oxford: Clarendon Press, 1967). For an account of the influence of these traditions on the 1789 "Declaration of Rights of Man and of the Citizen," see J.K. Wright, "National Sovereignty and the General Will: The Political Program of the Declaration of Rights," The French Idea of Freedom: The Old Regime and the Declaration of Rights of 1789 , ed. Dale Van Kley (Stanford: Stanford University Press, 1994), pp. 199-233.

102 The use of "pluralism" to refer to a politics probably dates from the work of Harold Laski. See his Studies in the Problem of Sovereignty (New Haven: Yale University Press, 1917); Authority in the Modern State (New Haven: Yale University Press, 1919); and "The Pluralist State," Philosophical Review (November 1919), reprinted in The Foundations of Sovereignty and Other Essays (New York: Harcourt, Brace, and Co., 1921), pp. $232-49$.

103 But, there is new interest in the issue. Pierre Rosanvallon recently has argued that pluralism in modern France, while absent in the theories and policies of government, prospered in civil society. [The Demands of Liberty: Civil Society in France Since the Revolution, trans. A. Goldhammer (Cambridge, MA: Harvard University Press, 2006).] J.A.Q. Gunn, on the other hand, finds evidence of attempts to think clearly about pluralistic politics during the Restoration. [When the French Tried to Be British: Party, Opposition, and the Quest for Civil Disagreement 1814-1848 (Montreal: McGill-Queen's University Press, 2009).] Annelien de Dijn traces a distinctive strain of pluralist political thought. [French Political Thought from Montesquieu to Tocqueville (Cambridge: Cambridge University Press, 2009).] For the connection with the thought of Constant, see my Benjamin Constant and the Birth of French Liberalism. 
supported religious, administrative, and political unity: the legacy of the absolutist and patrimonial state; the pervasive cultural and institutional influence of Catholicism; the residues of Cartesian rationalism and Enlightenment radicalism. And, it will need to take into account how these traditions were reinforced during the Revolution with critiques of the privileged order of the Old Regime, with fears of military defeat, and with anxieties about plots and conspiracies (of counterrevolutionaries, of monarchists, and of other revolutionaries). These traditions and forces created a political culture during the French Revolution that emphasized national unity and characterized political disagreement as unpatriotic, even treasonous. ${ }^{104}$ What was distinctive about the post-revolutionary thought of Benjamin Constant was the unique manner in which the three dimensions of French pluralism noted above - religious, political, and administrative - were combined to oppose what Lucien Jaume has termed the "unanimisme mystique" of Revolutionary culture. 105

Constant was a consistent champion of constitutional pluralism, insisting that it required consideration of political, religious, and administrative fronts. This needs emphasis because recent scholarship has often downplayed the importance of this ideological dimension of French liberal thought. Pierre Rosanvallon, for example, has viewed François Guizot as representative of early-nineteenth century French liberal thought, implying that we should take as normative Guizot's rejection of the revolutionary principle of popular sovereignty and his embrace of the principles of reason, truth, and justice. ${ }^{106}$ More recently, he defined French-style liberalism as "yoking the cult of law to the praise of the rationalizing state, [and] the notion of the rule of law with that of administrative power."107 Rosanvallon's view of French liberalism stresses its rationalistic roots and its centralizing impulse. 108 While this

104 There is an ongoing debate concerning the causes of the anti-pluralist nature of revolutionary political culture. François Furet and Keith Michael Baker highlight the deep ideological causes. [Furet, Interpreting the French Revolution, trans. E. Forster (Cambridge: Cambridge University Press, 1981); Baker, Inventing the French Revolution: Essays on French Political Culture in the Eighteenth Century (Cambridge: Cambridge University Press, 1990)]. Timothy Tackett focuses on the political radicalization of revolutionary actors between 1788 and 1791 . [Becoming a Revolutionary: The Deputies of the French National Assembly and the Emergence of a Revolutionary Culture 1789-1790 (Princeton: Princeton University Press, 1996); When the King Took Flight (Cambridge, MA: Harvard University Press, 2003); "Paths to Revolution: The Old Regime Correspondence of Five Future Revolutionaries," French Historical Studies, 32:4 (2009), pp. 531-54]. Barry M. Shapiro traces it to the experience of trauma experienced by representatives in the National Assembly during June and July 1789. [Traumatic Politics: The Deputies and the King in the Early French Revolution (University Park, PA: The Pennsylvania State University Press, 2009).]

105 Lucien Jaume, Le discours Jacobin et la démocratie (Paris: Fayard, 1989), this phrase p. 322.

106 Pierre Rosanvallon, Le Moment Guizot (Paris: Gallimard, 1985).

107 Pierre Rosanvallon, "Political Rationalism and Democracy in France" [originally pub. 1994], in Democracy Past and Future, ed. S. Moyn (New York: Columbia University Press, 2006), p. 130.

108 Recently, Rosanvallon has represented French ideas since the Revolution as a tradition that "emphasizes the centralizing tradition as well as the permanent antiliberal temptation stemming from the 'absolutization' of popular sovereignty and the states' claim to institute and instruct society." Rosanvallon contrasts this ideology with a social history that highlights the importance of the concrete existence of "intermediary bodies." This is an important contrast, but the ideological landscape is more varied than this suggests. Pierre Rosanvallon, The Demands of Liberty: Civil Society in France since the Revolution, this quote, p. 3. 
was an important component of one strain of French liberalism in the early nineteenth century, there was also a competing pluralist strain.109 Constant developed a political pluralism that insisted on administrative decentralization, on the protection of rights, on religious toleration, on political contestation, and on the institutional separation of different branches of government. His constitutional proposals reflected these pluralistic liberal concerns.

Fecha de envío / Submission Date: 5/12/2014

Fecha de aceptación / Acceptance Date: 24/05/2015

109 Lucien Jaume is a good guide here. See his Individu effacé: ou le paradoxe du libéralisme français (Paris: Fayard, 1998). 